\title{
The Effect of Injection Timings on Performance and Emissions of Compressed Natural-Gas Direct Injection Engine
}

\author{
Saad Aljamali, Shahrir Abdullah, Wan Moh Faizal Wan Mahmood, and Yusoff Ali \\ Department of Mechanical and Materials Engineering, Faculty of Engineering and Built Environment, \\ Universiti Kebangsaan Malaysia (UKM), 43600 Bangi, Selangor, Malaysia
}

Correspondence should be addressed to Saad Aljamali; saadaljamali@gmail.com

Received 20 December 2015; Revised 9 March 2016; Accepted 9 March 2016

Academic Editor: Ishwar K. Puri

Copyright (C) 2016 Saad Aljamali et al. This is an open access article distributed under the Creative Commons Attribution License, which permits unrestricted use, distribution, and reproduction in any medium, provided the original work is properly cited.

This experimental part investigates the effect of injection timing on performance and emissions of homogenous mixture compressed natural-gas direct injection. The engine of $1.6 \mathrm{~L}$ capacity, 4 cylinders, spark ignition, and compression ratio of 14 was used. Performance and emission were recorded under wide-open throttle using an engine control system (Rotronics) and the portable exhaust gas analyser (Kane). The engine was tested at speed ranging from 1500 revolutions per minute (RPM) to 4000 RPM with 500 RPM increments. The engine control unit (ECU) was modified using Motec 800. The injection timings investigated were at the end of injection (EOI) $120 \mathrm{bTDC}, 180 \mathrm{bTDC}, 300 \mathrm{bTDC}$, and $360 \mathrm{bTDC}$. Results show high brake power, torque, and BMEP with 120 as compared with the other injection timings. At 4000 RPM the power, torque, and BMEP with 120 were $5 \%$ compared to that with 180. Furthermore, it shows low BSFC and high fuel conversion efficiency with 120 . With 360 , the engine produced less CO and $\mathrm{CO}_{2}$ at higher speeds.

\section{Introduction}

The search of alternative fuels is becoming a more important concern worldwide. This is due to few obvious reasons, specifically the fluctuation of oil price, a declining trend of oil production internationally, health-issues due to pollution, and an alarming global climate change [1]. Compressed natural-gas was chosen as an alternative fuel for many reasons: high-octane number, fast flame speed, ability to be run with high compression ratio engines, low emission, and lower price compared with traditional fuel (petrol and diesel). On the other hand, it produces less power. To increase the brake power, solution is to use a direct injection with suitable compression ratio to avoid knocking phenomenon.

The CNG air fuel ratio is 17.23 so the percentage of fuel required is less compared to other fuels (gasoline 14.37, diesel 14.4) [2]. There occurred an ideal fuel injection timing where the maximum cylinder pressure and the maximum rate of heat release obtained their maximum values along with the shortest combustion durations, the shortest heat release duration closing to the top dead center but keeping the low level of $\mathrm{HC}$ and $\mathrm{CO}$ emissions [3].
The injection timing is a very important parameter to ensure better combustion, and this depends on valve timing and ignition timing; those are main factors to optimize the heat release which has effects on the performance of the engine [4]. In this CNGDI engine the fuel injection pressure is 20 bar. To obtain the optimum injection timing this engine was tested with different injection timings. In an investigation that used a single cylinder with homogenous and stratified piston [5] found that the best injection timing was from $120 \mathrm{bTDC}$ to $180 \mathrm{bTDC}$ to reach a better performance.

In an experiment using a single-cylinder methanol engine stratified combustion at 1600 RPM with full load, the optimization of injection and ignition timing lead to an improvement of brake specific fuel consumption by $10 \%$ [6]. In another experiment using a single-cylinder diesel engine fueled by natural-gas, the test results with advanced injection timing showed that each alternative fuel requires injection advanced appropriately to its delay period. It was found that advanced timing tended to incur a minor increase in fuel consumption. There was an important reduction in $\mathrm{CO}_{2}$ emissions with advanced timing [7]. 
By using rapid compression machine the effect of injection timing was tested on natural-gas direct injection. Results have shown that early injection leads to longer duration of the initial combustion. However, late injection leads to a longer duration of the late combustion. Early injection showed lower $\mathrm{CO}$ concentration in the combustion products while late injection gave lower $\mathrm{NO}_{x}$ [8]. In another study using a single cylinder, with compression ratio of 14 , natural-gas direct injection was tested. Using a partially stratified combustion (PSC) range start of injection timing (SOI) $(-130$ to -50 degrees aTDC), results showed important improvement in combustion stability, phasing, and HC emissions [9]. Furthermore, in another study using natural-gas direction injection with late injection timing and lean combustion, results showed indicated mean effective pressure (IMEP) decrease with the lambda increase [10]. Additionally, another study used lean combustion (stratified) direct injection gasoline fueled single cylinder; results showed smoke emission, and incomplete combustion products were increased at the late injection timing due to increased close by rich area of the mixture. On the other side, nitrogen oxides $\left(\mathrm{NO}_{x}\right)$ emissions were reduced while indicated mean effective pressure (IMEP) was increased as the injection timing was retarded [11].

In CNGDI engine, using different hydrogen blends $(0 \%$, $3 \%, 5 \%$, and $8 \%$ ), fuel injection timing was tested with wideopen throttle and lambda $(=1)$. The results showed that the engine performance (e.g., brake torque, brake power, and BMEP), the cylinder pressure, and the heat release have the highest values of the injection timing of $180 \mathrm{bTDC}$, followed by the $300 \mathrm{bTDC}$ and the $120 \mathrm{bTDC}$ [12].

The empirical part using four-cylinder natural-gas direct injection combustion is tested with a kind of piston crown that could generate homogenous mixture during compression stroke. The objective of this investigation is to study the optimum injection timing by using different points to obtain a higher engine performance with lower emissions. For ignition timing, it was fixed for all tests.

\section{Materials and Methods}

A 1.6-litre, $7.6 \mathrm{~cm}$ bore, $8.8 \mathrm{~cm}$ stroke, and 4-cylinder spark ignition engine direct injection filled with compressed natural-gas were installed to control CNG operation. The engine specifications are given in Table 1 . CNG was used as fuel. The substantial advantage that CNG has in antiknock quality is related to the higher auto ignition temperature and higher octane number compared to that of gasoline as shown in Table 2. Furthermore, CNG has a high air fuel ratio (A/F)s and heating value with 17.23 and $47.377 \mathrm{MJ} / \mathrm{kg}$, respectively. The composition of CNG used in Malaysia is as shown in Table 3.

An engine control system and portable exhaust gas analyser were used for controlling engine operations and recording engine performance and emission's data. The KRONOS 4 software is the software of the test bench as shown in Figure 1. Results were recorded in steady-state condition so ambient pressure, ambient temperature, and humidity were recorded to estimate air inlet density. Portable exhaust gas analyser Kane-May which is an International Organization of
TABLE 1: Engine specifications.

\begin{tabular}{lcc}
\hline Parameter & Value & Unit \\
\hline Number of cylinders & 4 & - \\
Type & Inline & - \\
Capacity & 1596 & $\mathrm{~cm}^{3}$ \\
Bore & 76 & $\mathrm{~mm}$ \\
Stroke & 88 & $\mathrm{~mm}$ \\
Connecting rod length & 131 & $\mathrm{~mm}$ \\
Crank radius & 44 & $\mathrm{~mm}$ \\
Compression ratio & 14 & - \\
Intake valve opening & 12 & $\mathrm{bTDC}$ \\
Intake valve closing & 48 & $\mathrm{aBDC}$ \\
Exhaust valve opening & 45 & $\mathrm{bBDC}$ \\
Exhaust valve closing & 10 & $\mathrm{aTDC}$ \\
Maximum intake valve lift & 8.1 & $\mathrm{~mm}$ \\
Maximum exhaust valve lift & 7.5 & $\mathrm{~mm}$ \\
\hline
\end{tabular}

TABLE 2: Combustion related properties of gasoline and CNG.

\begin{tabular}{lcc}
\hline Properties & Gasoline & CNG \\
\hline Motor octane number & $80-90$ & 120 \\
Molar mass (g/Mol) & 110 & 16.04 \\
Carbon weight fraction (mass\%) & 87 & 75 \\
$(\mathrm{~A} / \mathrm{F}) \mathrm{s}$ & 14.7 & 17.23 \\
Stoichiometric mixture density $\left(\mathrm{kg} / \mathrm{m}^{3}\right)$ & 1.38 & 1.24 \\
Lower heating value $(\mathrm{MJ} / \mathrm{kg})$ & 43.6 & 47.377 \\
Lower heating value of stoic. mixture $(\mathrm{MJ} / \mathrm{kg})$ & 2.83 & 2.72 \\
Flammability limits $(\mathrm{Vol} \%$ in air) & $1.3-7.1$ & $5-15$ \\
Spontaneous ignition temperature $\left({ }^{\circ} \mathrm{C}\right)$ & $480-550$ & 645 \\
\hline
\end{tabular}

TABLE 3: Typical composition (Vol.\%) of CNG (source: PETRONAS Research \& Scientific Services).

\begin{tabular}{lcc}
\hline Component & Symbol & Volumetric\% \\
\hline Methane & $\mathrm{CH}_{4}$ & 94.42 \\
Ethane & $\mathrm{C}_{2} \mathrm{H}_{6}$ & 2.29 \\
Propane & $\mathrm{C}_{3} \mathrm{H}_{8}$ & 0.03 \\
Butane & $\mathrm{C}_{4} \mathrm{H}_{10}$ & 0.25 \\
Carbon dioxide & $\mathrm{CO}_{2}$ & 0.57 \\
Nitrogen & $\mathrm{N}_{2}$ & 0.44 \\
Others & $\left(\mathrm{H}_{2} \mathrm{O}^{+}\right)$ & 2.0 \\
\hline
\end{tabular}

Legal Metrology (OIML) class one certificate was calibrated for each test to get correct results. ECU setting is modified using Motec software by changing the end of injection (EOI) to $120 \mathrm{bTDC}, 180 \mathrm{bTDC}, 300 \mathrm{bTDC}$, and $360 \mathrm{bTDC}$.

The engine was running under full load wide-open throttle. The homogenous piston crown used is shown in Figure 2.

\section{Results and Discussion}

3.1. Brake Power. Figure 3 shows the brake power versus engine speed from 1500 RPM to 4000 RPM. Results showed 

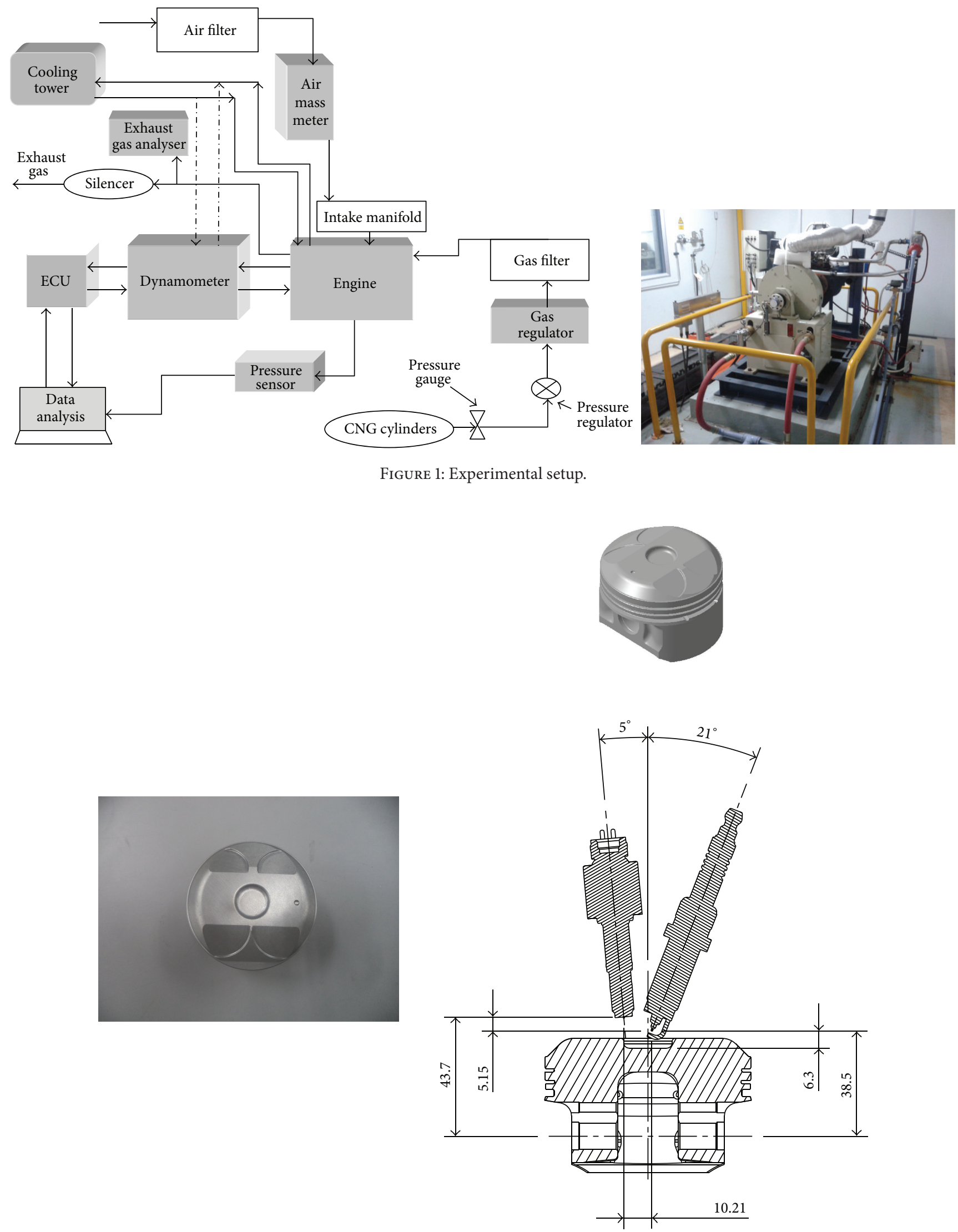

Section view C-C

FIgURE 2: Homogenous piston crown. 


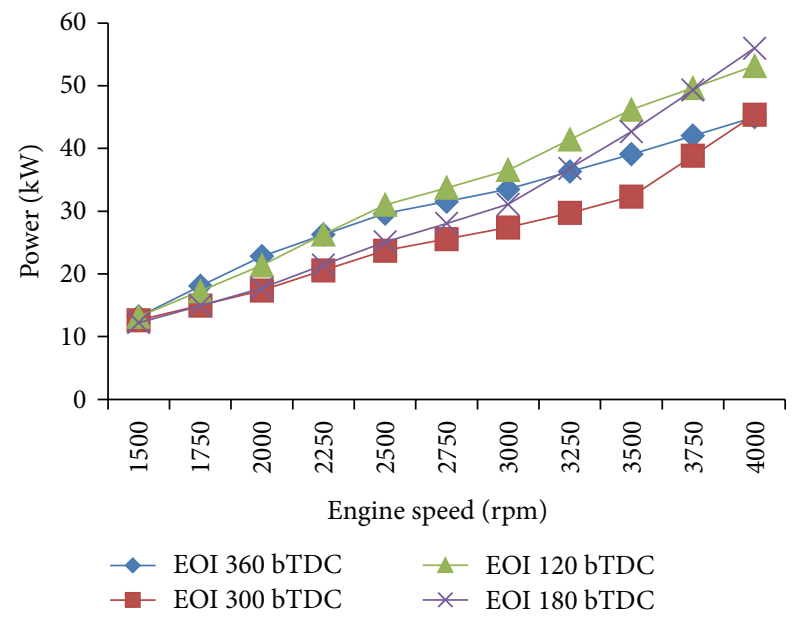

Figure 3: Brake power versus engine speed.

high brake power with EOI 120 bTDC. At 4000 RPM, the power was less $5 \%$ compared to EOI $180 \mathrm{bTDC}$. The increase of power was due to many reasons which include high pressure and high-heat release. Furthermore, the injection time occurs while both valves are closed; this led to lean mixture and reduced fuel consumption. Additionally, the late injection timing with high pressure and suitable combustion duration increase the engine performance and will get good propagation flame. Compared to another study by Zeng et al. fuel injection timing had a large effect on the engine performance, combustion, and emissions and these influences became mainly in the case of late injection cases. However, the optimum fuel injection timing with high pressure and high-heat release will get high values [3]. For homogenous charge combustion operation engine, the injection timing is set at early in compression stroke to ensure the better fuel/air mixing [4]. The power is $13.18 \mathrm{KW}$ at $1500 \mathrm{RPM}$ and $53.12 \mathrm{KW}$ at $4000 \mathrm{RPM}$ for EOI $120 \mathrm{bTDC}$.

3.2. Brake Torque. Figure 4 shows the brake torque versus engine speed with different injection timing $(120,180,300$, and 360) bTDC. Results showed the high torque with the EOI 120 bTDC with 13.6\%, 18\% compared to EOI 300 bTDC and EOI $360 \mathrm{bTDC}$, respectively. The maximum torque was recorded at $4000 \mathrm{RPM}$ with $133.8 \mathrm{~N} \cdot \mathrm{m}$ at EOI $180 \mathrm{bTDC}$, while it was $126.8 \mathrm{~N} \cdot \mathrm{m}$ at EOI $120 \mathrm{bTDC}$ with less $5 \%$. In another study [13] found that the maximum torque occurred at $5500 \mathrm{RPM}$ with $123.47 \mathrm{~N} \cdot \mathrm{m}$ less $(2.7 \%, 8.36 \%)$ compared to EOI $120 \mathrm{bTDC}$ and EOI $180 \mathrm{bTDC}$, respectively. The main factors affecting the brake torque are the lack of chemical energy conversion to mechanical energy, which is strongly related to volumetric efficiency, fuel mixing, net heat release rate, and cylinder pressure.

3.3. BSFC. Figure 5 shows the brake specific fuel consumption (BSFC) versus engine speed. Results showed the less BSFC at EOI $120 \mathrm{bTDC}$. BSFC at EOI $120 \mathrm{bTDC}$ is $194.8 \mathrm{~g} / \mathrm{KW} \cdot \mathrm{h}$ at $1500 \mathrm{RPM}$ and decreases at high speed until $88.34 \mathrm{~g} / \mathrm{KW} \cdot \mathrm{h}$. It is less $(13.2 \%, 6.5 \%$, and 12.5$)$ at a low speed,

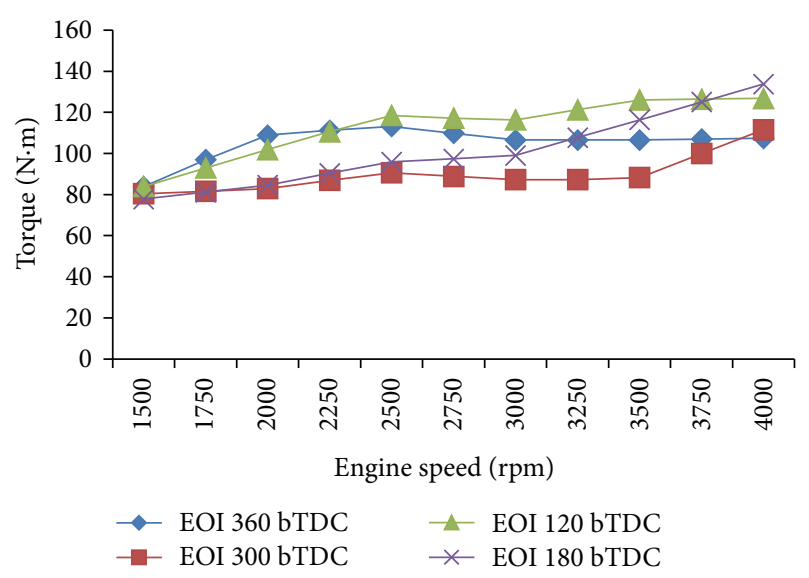

FIGURE 4: Brake torque versus engine speed.

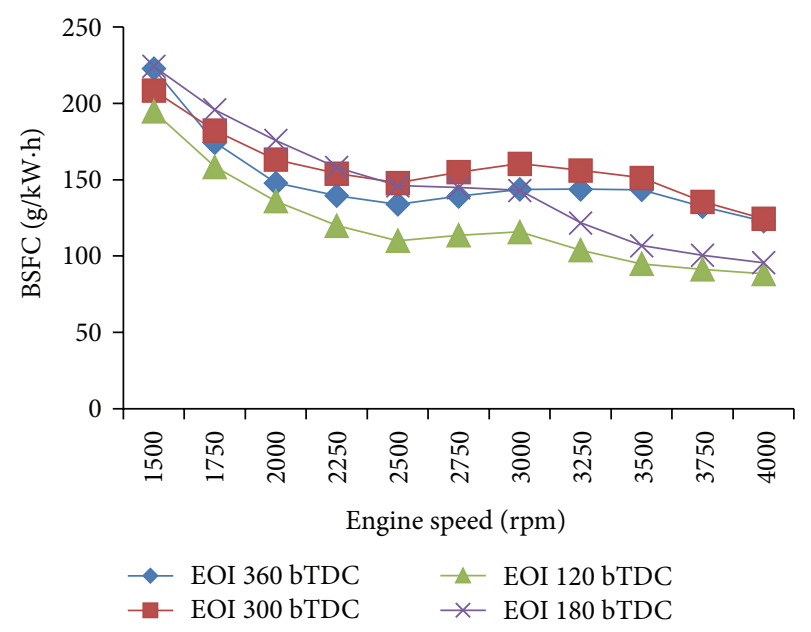

FIGURE 5: BSFC versus engine speed.

less $(7.7 \%, 29 \%$, and $28 \%$ ) at high speed compared to EOI $180 \mathrm{bTDC}$, EOI $300 \mathrm{bTDC}$, and EOI $360 \mathrm{bTDC}$, respectively.

3.4. BMEP. Figure 6 illustrates brake mean effective pressure (BMEP) versus engine speed. Results showed the BMEP increase with the engine speed increase. The engine with EOI $120 \mathrm{bTDC}$ produced maximum value $10 \mathrm{Bar}$ at $4000 \mathrm{RPM}$ more $(17 \%, 18 \%)$ compared to EOI 300 bTDC and 360 bTDC, respectively. The heat released rate, good mixture, and sufficient combustion time affected the BMEP.

3.5. Fuel Conversion Efficiency. Figure 7 shows the fuel conversion efficiency $\left(\eta_{f}\right)$ versus engine speed. Results showed the maximum value $86 \%$ at $4000 \mathrm{RPM}$ in EOI $120 \mathrm{bTDC}$. On the whole, all speed ranges of the fuel conversion efficiency are high in EOI $120 \mathrm{bTDC}$. The minimum value recorded was $33.8 \%$ at 1500 RPM in EOI 180 bTDC but at 4000 RPM the minimum value was observed at EOI $300 \mathrm{bTDC}$ with value $61 \%$. From previous results, high pressure and highheat release are main reasons to increase the fuel conversion efficiency. 


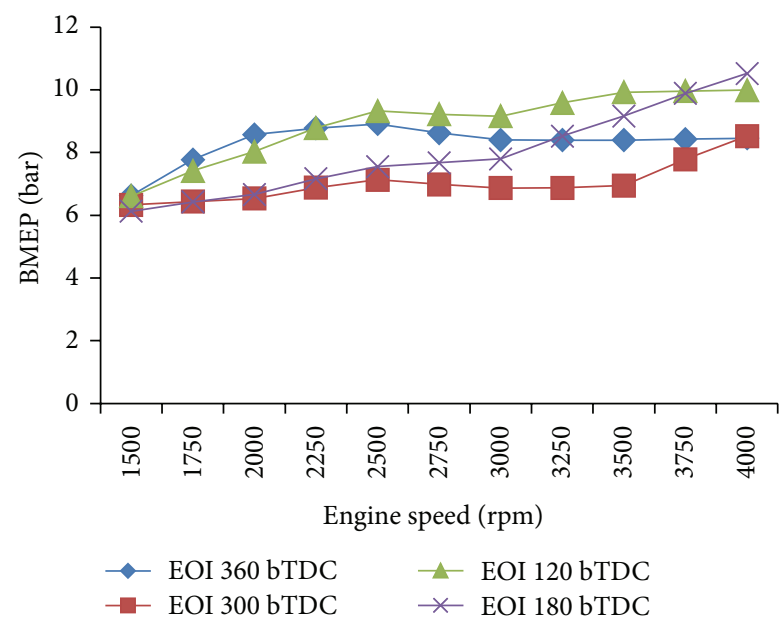

FIGURE 6: BMEP versus engine speed.

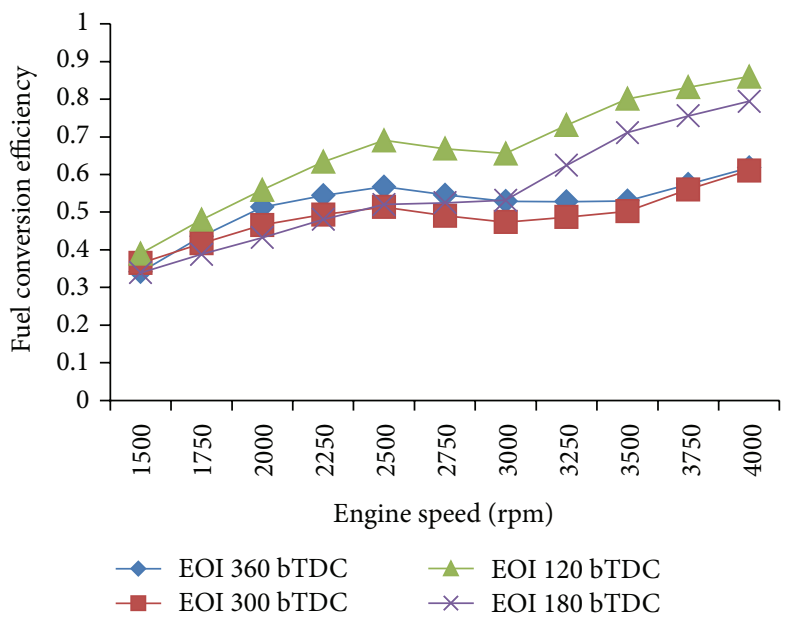

FIGURE 7: Fuel conversion efficiency versus engine speed.

3.6. Lambda. Figure 8 shows the lambda $(\lambda)$ versus engine speed. From the results, almost lambda was $\lambda \geq 1$. Results showed low values in low speed for EOI 120 bTDC with 0.845 , which is less than one; it means the mixture is rich. For high speeds, results show high lambda in EOI 120 bTDC. The maximum value was 1.46 at 4000 RPM in EOI 120 bTDC.

3.7. Volumetric Efficiency. Figure 9 illustrates the volumetric efficiency versus engine speed. The maximum value is at 1500 RPM in EOI 360 bTDC with 0.51 because the injection ends while the exhaust valve is still open which increases the air that flowed through the intake manifold and some fuel sweeps through exhaust manifold. In EOI 120 bTDC the volumetric efficiency is less at low speeds compared to the other injection timings.

3.8. Emissions. Figures 10,11 , and 12 show $\mathrm{CO}, \mathrm{CO}_{2}$, and $\mathrm{O}_{2}$, respectively, versus engine speed. In Figure 10 carbon monoxide $(\mathrm{CO})$ is less at EOI $360 \mathrm{bTDC}$ in whole speeds except at 1500 RPM it was less at EOI 120 bTDC with value

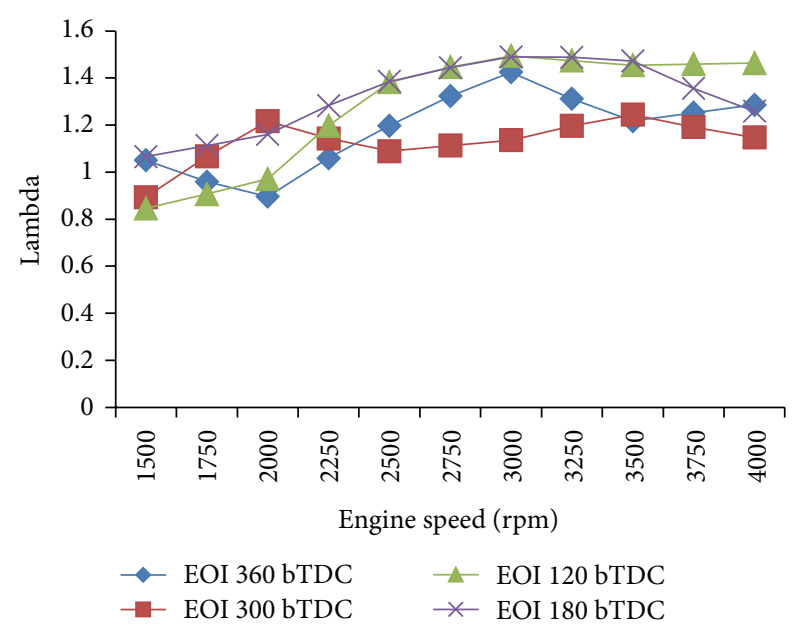

FIgURE 8: Lambda versus engine speed.

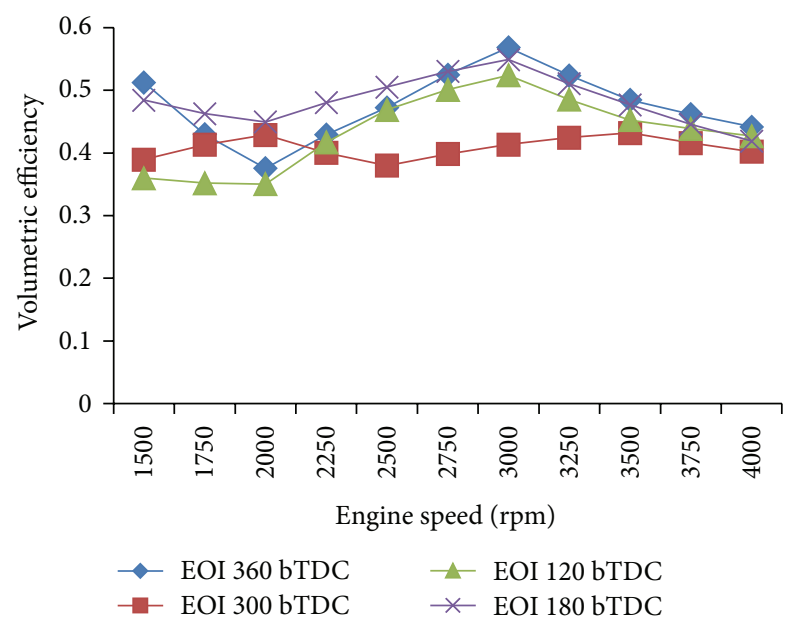

FIGURE 9: Volumetric efficiency versus engine speed.

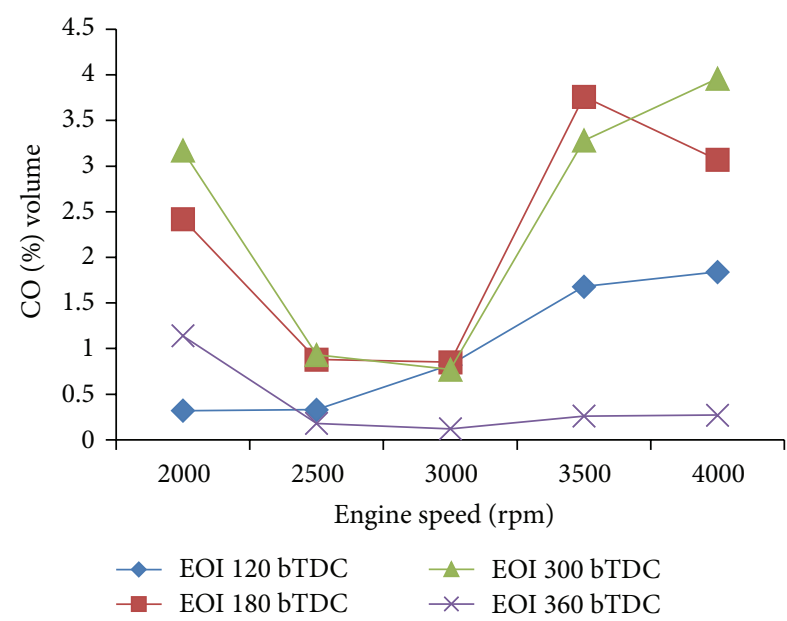

Figure 10: CO versus engine speed. 


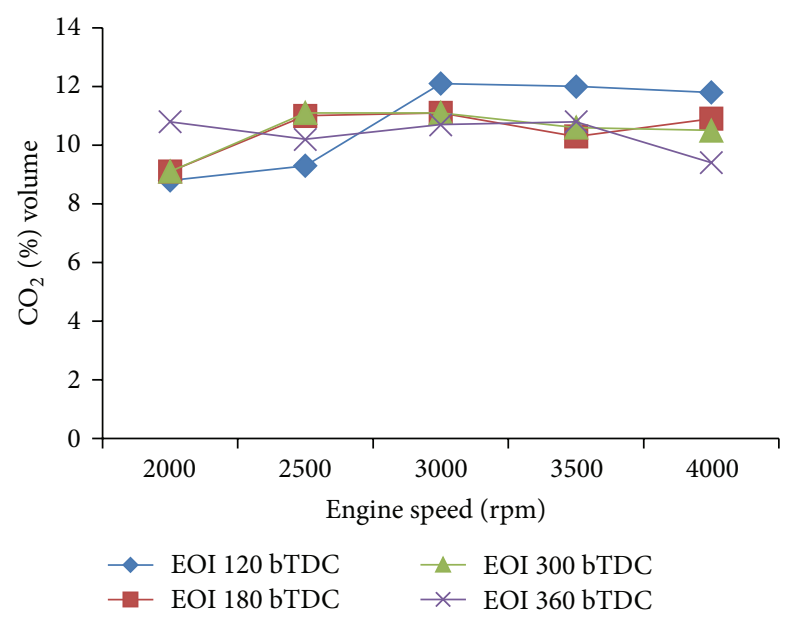

FIGURE 11: $\mathrm{CO}_{2}$ versus engine speed.

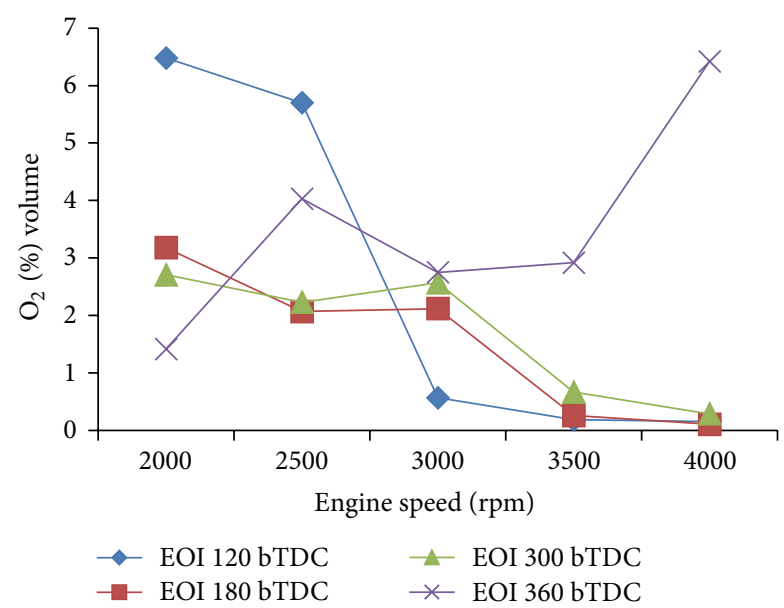

FIGURE 12: $\mathrm{O}_{2}$ versus engine speed.

$0.32 \%$ volume. The highest $\mathrm{CO}$ emission was at $300 \mathrm{bTDC}$, 4000 RPM with value of $3.96 \%$ volume. In Figure 11, results showed that carbon dioxide $\left(\mathrm{CO}_{2}\right)$ emission is less at EOI $120 \mathrm{bTDC}$ in low speeds but higher at high speed. The minimum value was recorded in $4000 \mathrm{RPM}$ at EOI $360 \mathrm{bTDC}$ with $9.4 \%$. The highest $\mathrm{CO}_{2}$ was obtained at $120 \mathrm{bTDC}$, 3000 RPM with value $12.1 \%$. The results showed the high value of $\mathrm{O}_{2}$ at EOI $360 \mathrm{bTDC}$ at high speed. In the low speed, $\mathrm{O}_{2}$ is high at EOI 120 bTDC.

\section{Conclusions}

Alternative fuels are becoming an important concern worldwide and natural-gas is an important choice instead of traditional fuels. Injection timing has a very close interrelation with the valve timing. Therefore, the setting of injection timing depended on both the timings of intake and exhaust valve. The injection timing also can be varied to depend on the combustion mode, engine load, and engine speed. From this investigation, the results can be summarized as follows:

(i) On average, the maximum brake power and brake torque are obtained at EOI $120 \mathrm{bTDC}$. (ii) At 4000 RPM brake power and brake toque are high at EOI $180 \mathrm{bTDC}$.

(iii) BSFC is reduced at EOI $120 \mathrm{bTDC}$.

(iv) Fuel conversion efficiency is high at EOI 120 bTDC on various engine speeds.

(v) CO is reduced at EOI $360 \mathrm{bTDC}$ in whole speeds except at 1500 RPM it was less at EOI 120 bTDC.

(vi) Results show that $\mathrm{CO}_{2}$ emission is also reduced at EOI $120 \mathrm{bTDC}$ in low speeds but higher at high speed.

\section{Competing Interests}

The authors declare that they have no competing interests.

\section{Acknowledgments}

The authors would like to acknowledge the support from Ministry of Science, Technology and Innovation of Malaysia (MOSTI) through Science fund research Grant 03-01-02SF0995.

\section{References}

[1] W. W. Pulkrabek, Engineering Fundamentals of the Internal Combustion Engine, Prentice-Hall, New York, NY, USA, 1997.

[2] J. B. Heywood, Internal Combustion Engine Fundamentals, McGraw-Hill, New York, NY, USA, 1988.

[3] K. Zeng, Z. Huang, B. Liu et al., "Combustion characteristics of a direct-injection natural gas engine under various fuel injection timings," Applied Thermal Engineering, vol. 26, no. 8-9, pp. 806813, 2006.

[4] Y. Ali, Z. Muhammad, and M. I. Khamas, "Valve timing and ignition issues in fuel system for compressed natural gas direct injection (CNGDI)," in Proceedings of 1st Conference and Exhibition on Natural Gas for Vehicles (ANGVA '05), 2005.

[5] M. K. Hassan, I. Aris, K. N. Zainuddin, and N. A. Alina, "Torque and power of CNGDI engine with two different piston crown shapes," Journal of Applied Sciences Research, vol. 5, no. 8, pp. 949-954, 2009.

[6] J. Li, C.-M. Gong, Y. Su, H.-L. Dou, and X.-J. Liu, "Effect of injection and ignition timings on performance and emissions from a spark-ignition engine fueled with methanol," Fuel, vol. 89, no. 12, pp. 3919-3925, 2010.

[7] O. M. I. Nwafor, "Effect of advanced injection timing on emission characteristics of diesel engine running on natural gas," Renewable Energy, vol. 32, no. 14, pp. 2361-2368, 2007.

[8] Z. Huang, S. Shiga, T. Ueda et al., "Effect of fuel injection timing relative to ignition timing on the natural-gas direct-injection combustion," Journal of Engineering for Gas Turbines and Power, vol. 125, no. 3, pp. 783-790, 2003.

[9] P. Zoldak and J. Naber, "Spark ignited direct injection natural gas combustion in a heavy duty single cylinder test enginestart of injection and spark timing effects," SAE Technical Paper 2015-01-2813, 2015.

[10] F. Y. Hagos, A. R. A. Aziz, S. A. Sulaiman, and Firmansyah, "Combustion characteristics of late injected CNG in a spark ignition engine under lean operating condition," Journal of Applied Sciences, vol. 12, no. 23, pp. 2368-2375, 2012. 
[11] H. Oh and C. Bae, "Effects of the injection timing on spray and combustion characteristics in a spray-guided DISI engine under lean-stratified operation," Fuel, vol. 107, pp. 225-235, 2013.

[12] S. E. Mohammed, M. B. Baharom, A. R. A. Aziz, and Firmansyah, "The effects of fuel-injection timing at medium injection pressure on the engine characteristics and emissions of a CNGDI engine fueled by a small amount of hydrogen in CNG," International Journal of Hydrogen Energy, vol. 36, no. 18, pp. 11997-12006, 2011.

[13] M. A. Kalam and H. H. Masjuki, "An experimental investigation of high performance natural gas engine with direct injection," Energy, vol. 36, no. 5, pp. 3563-3571, 2011. 


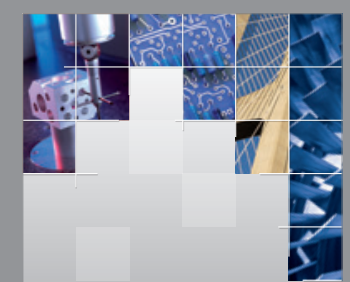

\section{Enfincering}
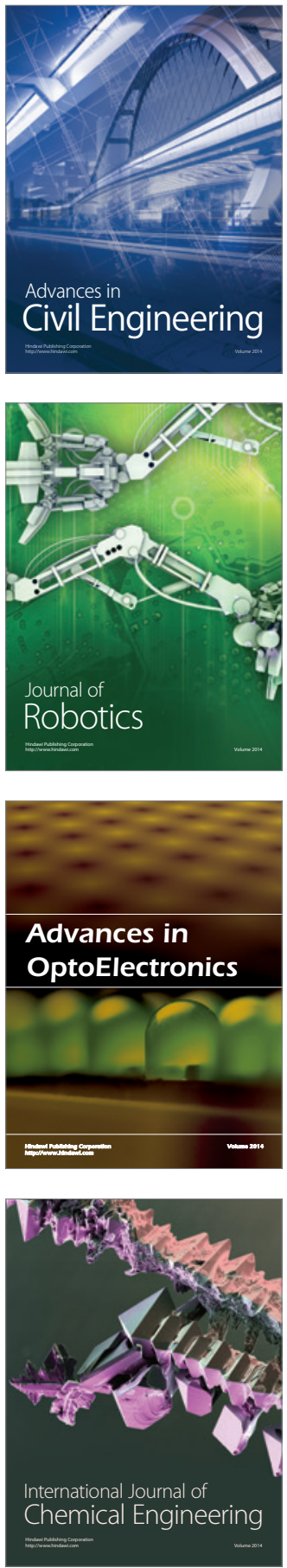

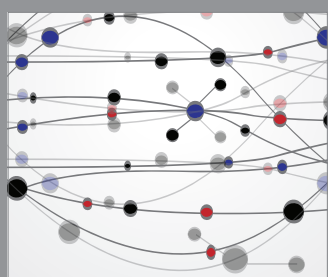

The Scientific World Journal

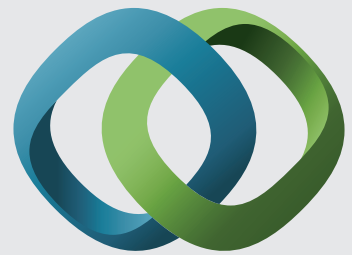

\section{Hindawi}

Submit your manuscripts at

http://www.hindawi.com
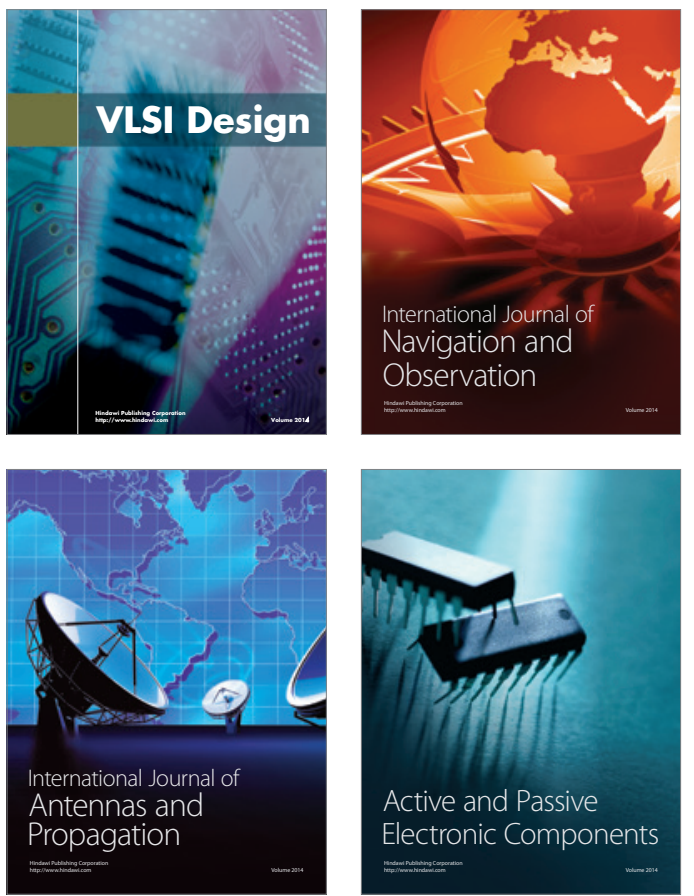
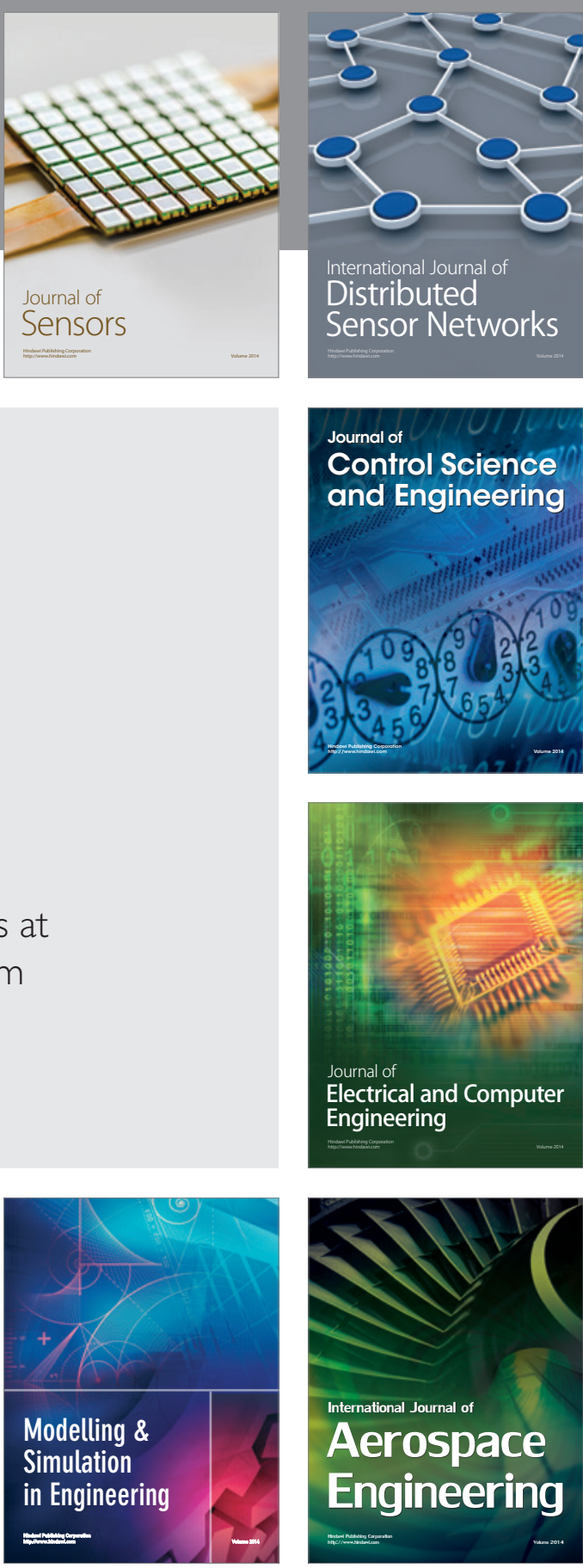

International Journal of

Distributed

Sensor Networks

Journal of

Control Science

and Engineering
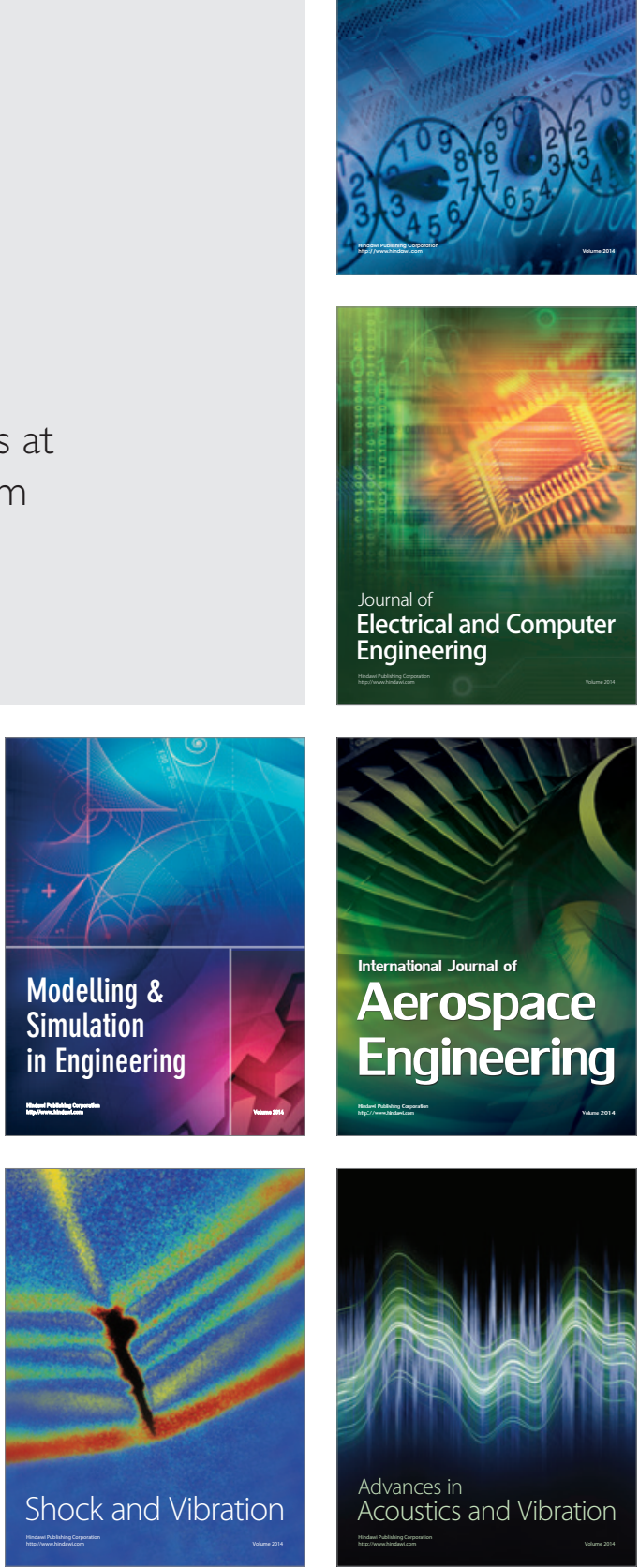